\title{
Community Environmental Monitoring: the management of commons in Cassurubá Extractive Reserve
}

${ }^{I}$ Master's degree and PhD student in Biodiversity in Conservation Units at Jardim Botânico Research Institute of Rio de Janeiro, National School of Tropical Botany; Environmental Analyst at Chico Mendes Institute for Biodiversity Conservation, Chapada dos Guimarães, MT, Brazil.

II Master's degree in Environmental Sciences and Technologies at Federal University of Southern Bahia, Belo Horizonte, MG, Brazil.

III Master's student in Collective Health at Federal University of Mato Grosso; Environmental Analyst at Chico Mendes Institute for Biodiversity Conservation, Chapada dos Guimarães, MT, Brazil.

\author{
Marcelo Lopes \\ Pedro Henrique Dias Marques \\ Priscilla Correa de Moura Estevão
}

\begin{abstract}
The aim of the current study is to address the right of Traditional Peoples and Communities (TPC) to participate in the environmental protection of their traditional territories in Extractive Reserves (RESEX), based on the analysis of the concrete Community Environmental Monitoring (CEM) case in Cassurubá RESEX. The conceptual framework of the topic was based on studies and theories focused on approaching the management commons. Next, the legal, positive and conceptual aspects of the national and international legal order, which outlines the scope of social participation in environment-related matters, were analyzed. Finally, the history, main features and institutional context CEM is inserted in were also analyzed. Action-research, participant observation and conversation meetings were the methodological instruments adopted in the current study. Indeed, CEM is a good instrument for the management of commons, mainly because it guarantees the rights of TPCs.
\end{abstract}

Keywords: Commons; Extractive reserve; Community environmental monitoring; Participative management; Protected Area.

São Paulo. Vol. 24, 2021

Original Article

DOI: http://dx.doi.org/10.1590/1809-4422asoc20190153r2vu2021L1AO 


\section{Introduction}

The socio-environmental conflict between Traditional Peoples and Communities ${ }^{1}$ (TPC) and Conservation Units (CU) is more evident if one takes into consideration full $\mathrm{CU}$ protection cases that have more restrictive land-use rules. This type of conflict is often investigated by several experts who take the work entitled O Mito Moderno da Natureza Intocada (The Modern Myth of Untouched Nature) by Antônio Carlos Diegues (2001b) as theoretical reference in the scientific literature. Sustainable-use CU categories that allow managed natural resource using - such as Extractive Reserves (RESEX) - represent an important conceptual and normative advancement of the Brazilian State (DIEGUES, 2001a). However, they are not capable of solving a series of socio-environmental conflicts between State and TPC (CHRISTMANN; VIEIRA, 2014).

Environmental inspections are treated as of exclusive responsibility of the State and are overall performed by environmental agencies (ANDRADE, 2014). These inspections are perceived in most conflicts between TPCs and CUs. Nowadays, environmental inspections are the main instrument used by environmental agencies to repress and punish degradation actions foreseen as environmental crime by the Brazilian legislation. As environmental inspections are based on coercion and punishment to enable social control, it is inevitable that, in several situations, they lead to undesired increased tension between public inspection agents and TPCs (GALDINO, 2016). Thus, Elinor Ostrom (1990) has analyzed the theory of the State by Thomas Hobbes - which is constitutive of several Modern State models - in order to better understand the evolutionary process experienced by institutions in the management of commons. In order to do so, she addressed important theoretical aspects about coercive performance and monopoly on the use of force by the State:

As Hobbes first formulated the theory, individuals who independently engage in protection activities overinvest in weapons and surveillance and consequently live in constant fear. If a ruler gains a monopoly on the use of force, the ruler can use coercion as the fundamental mechanism to organize a diversity of human activities that will produce collective benefits. (OSTROM, 1990, p. 41).

The current article has adopted the concept of commons developed by Ostrom in her classic work entitled Governing the Commons - The Evolution of Institutions for Collective Action (1990). Commons are material or immaterial goods commonly enjoyed by human society. They are not subject to any unquestionable framework based on the private- or public-state nature dichotomy. Commons are herein associated with traditional territories and natural elements managed by local populations, depending on their own culture.

Despite their high social cost, both for the State and TPCs, conventional methods adopted by environmental agencies to carry out environmental inspections, in associa-

1 - As Paul E. Little (2002) addresses "Traditional Peoples and Communities" in his preambular analysis in the article "Social Territories and Traditional Peoples in Brazil: for an anthropology of territoriality", we herein ask for permission to use this concept. 
tion with insufficient administrative structure (FEENY et al., 1990; DI PIETRO, 2012), have low efficiency in sustainable-use CUs. It happens due to the following factors: predictability of actions, since TPCs can perceive and tell each other about the time of arrival, incursion and departure of inspection teams; insufficient knowledge, on the part of inspection agents, about the territory and natural processes taking place in these environments, such as tides, climate, moon and night; shades of institutional culture, which is capable of legitimizing real and symbolic state violence (BOURDIEU, 2014) and holds a certain police and ostensive stance; diminished TPC participation, empathy and collaboration; high costs with inspection operations and deficient managerial resources in relation to the size and complexity of protected areas (GALDINO, 2016; DI PIETRO, 2012; FEENY et al., 1990; MOURA, 2014).

However, expecting knowledge by environmental inspection agents to be comparable to the traditional intergenerational knowledge accumulated by TPCs in their life territories would not be a clear prognosis, even if the managerial structures were ideal and the specific training processes could improve both state inspections and the institutional culture. Thus, the ideal scenario for the environmental protection of traditional territories would result from combined and complementary efforts of genuinely involved TPCs; better structured and trained state agents; and other engaged social actors with legitimate concern for commons.

Cassurubá Extractive Reserve - which is the scenario of the current case study (Figure 1) - is a federal sustainable-use CU managed by Chico Mendes Institute for Biodiversity Conservation (ICMBio - Instituto Chico Mendes de Conservação da Biodiversidade). The institute, in its turn, is a federal autarchy linked to the Ministry of the Environment (BRASIL, 2007); therefore, it is inserted in this institutional context. RESEX was created by presidential decree on June $5^{\text {th }}, 2009$ (BRASIL, 2009), after the reaction from social and environmental movements, non-governmental organizations, fishermen and shellfish gatherers to the shrimp farming project developed by the Shrimp Breeders' Cooperative, Far South Bahia State (Coopex) (MELLO, 2015). It covers approximately 100,000 hectares and aims at protecting and promoting the sustainable use of the estuarine complex and coastal sea strip located among Alcobaça, Caravelas and Nova Viçosa counties, far South Bahia State. 
Figura 1 - Geographic location of Cassurubá Extractive Reserve and its buffer zone

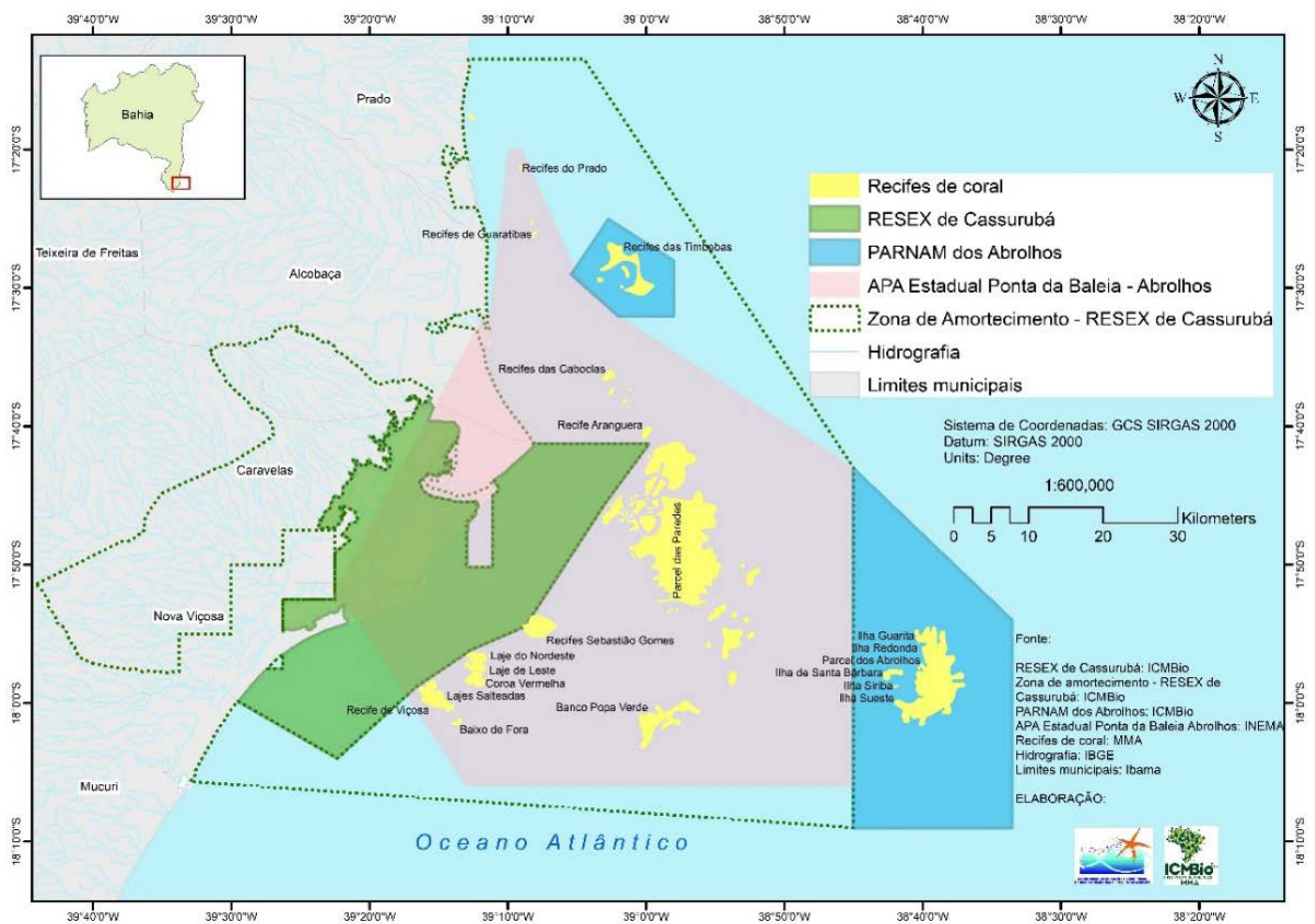

Elaborated by: Marília das Graças Mesquita Repinaldo (2019)

This coastal environment shelters the territory and the traditional way of life of fishermen, shellfish gatherers and small farmers. The territory comprises the total number of 1,358 acknowledged families (ICMBIO, 2019b). Shrimp fishing and swamp ghost crab capturing stand out among dozens of fishing gear and knowledge practiced by extractivist agents.

Accordingly, the government adopts several species conservation strategies, such as reproduction seasons, when fishing is forbidden by law to protect species undergoing breeding process (DIAS NETO, 2017). Nowadays, Cassurubá RESEX has six reproductive seasons associated with the following species: Xiphopenaeus kroyeri (Atlantic seabob), Farfantepenaeus subtilis and Farfantepenaeus brasiliensis (Southern brown shrimp), Litopenaeus schmitti (white shrimp), Ucides cordatus (swamp ghost crab) and Centropomus spp (sea bass). These reproduction seasons last nine months every year ${ }^{2}$, a fact that requires enormous and perennial effort from the management of this CU (ICMBIO, 2019b).

The management team and artisanal fishermen of Cassurubá RESEX have planned and implemented the Community Environmental Monitoring (CEM) after the second

2 - The swamp ghost crab reproduction season extends from January to March, the shrimp reproduction seasons extend from April to May and from September to October, whereas sea bass reproduction season extends from May to July. 
half of 2015 to overcome the aforementioned conceptual, structural and factual limitations. CEM has received financial resources from the Protected Marine and Coastal Areas Project (GEFMAR - Projeto Áreas Marinhas e Costeiras Protegidas) from the very beginning (BRAZIL, 2014; LEÃO, 2017). They were used to pay daily fees and to purchase fuel for community monitors, in compliance with the positive stimulus conceptualized by Mancur Olson (2015). CEM's creation was inspired by the currently extinct Voluntary Environmental Agents Program (IBAMA, 2005; AMÂNCIO, 2006), and it was adapted to the local reality through collective collaborations of those involved in it.

It is worth mentioning two important milestones with respect to the formal and institutional aspects of CEM. The first milestone lies on the Action Plan by Cassurubá RESEX Deliberative Council, which was prepared along with extractivist agents in 2015. The Plan clearly instructs the RESEX management team to involve the extractivist agents in environmental protection actions implemented in the CU (ICMBIO, 2015). The second milestone refers to CEM's incorporation to management programs established in Cassurubá RESEX Management Plan (ICMBIO, 2019b). This participatory environmental protection system - developed and implemented by ICMBio community monitors, partners, fellows and servers - was also selected and presented at the $4^{\text {th }}$ International Marine Protected Areas Congress (IMPAC4) ${ }^{3}$ held in La Serena - Coquimbo, Chile, in 2017.

\section{Methodology}

The aim of the current research was not only to evaluate technical elements, but to identify qualitative factors and cognitive elements in the scenario where one seeks to overcome one of the greatest challenges faced by science nowadays, namely: repetition (FLORIANI, 2001). Participatory methodology and action-research were the methodological approaches adopted in the current case. The current research focused on solving a collective issue and was inspired in the movements of involved social actors. Thus, events, developments and improvements of this social process were the main elements of the herein analyzed reality (THIOLLENT, 1986). Michel Thiollent was very precise in his definition of action-research:

Action-research is a type of social research with empirical basis that is designed and carried out in close association with an action or solution of a collective problem and in which researchers and participants representing the situation or problem are involved in a cooperative or participatory way. (THIOLLENT, 1986, p. 14).

Participant observation - a methodology focused on the interaction between researcher and subjects - was herein adopted. It was in line with the action-research to see beyond what is seen by observing reality itself, individuals' bodily actions and environmental features in a holistic way, and by taking into account social, environmental,

3 - The International Marine Protected Areas Congress focused on discussing about the association between Marine Protected Areas and global changes, about the importance of the close link between communities and the conservation of oceans, as well as on reviewing successful management cases. 
political and cultural aspects (SPRADLEY, 1980). The application pf participant observation requires different conditions; however, according to Paulowski and collaborators (2016), observers actively participate in information collection processes, and it requires them to have substantial empathy and resilience to adapt to each situation. Thus, researchers must immerse themselves in the daily lives of traditional communities, since this experience makes the information collected to represent the local dynamics reliable (MÓNICO et al., 2017).

Participant observation was largely exercised in conversation circles to enable discourse analysis and, based on this methodological device, to elaborate gestures of reading and possible interpretations about discursive formations by individuals involved in it (ORLANDI, 1999). In addition, these techniques allowed researchers to have a valuable experience that has greatly contributed to achieve the herein proposed aim. Experiencing the debate about traditional territory and the management of natural resources was essential to better understand the local reality. Based on watchful eye and empathetic listening, researchers have analyzed and systematized different statements, intonations, eloquent silences, conflicts and convergences - among other relevant aspects - in field diaries to help better understanding reality through of traditional communities' perspective.

Based on these theoretical-methodological instruments, it is important highlighting that CEM was designed, implemented and improved through the involvement and leading role played by artisanal fishermen from Cassurubá RESEX. Members of this CU management team, environmental analysts, scholarship holders and partners have played the role of facilitators, participating observers and, in the case of analysts, the role of implementers of environmental policies and legislation.

The methodology adopted in the current action-research aimed at finding solutions to the following inquiries: can (or should) TPCs be involved in the environmental protection of RESEXs, of their traditional territories and, consequently, of their natural resources? Is it possible improving the environmental protection of a given RESEX by completing conventional actions of environmental inspection exclusively carried out by state agents, through active TPC participation?

CEM has sought to answer these questions with practical learning measures and processes. It was institutionally protected by the constitutional principle, according to which, protecting the environment is a right and a duty of all (BRASIL, 1988). CEM, which was inspired by the previous experience of IBAMA Voluntary Environmental Agents Program (2005), was implemented as a pilot project in Barra de Caravelas community, in the second annual shrimp reproduction season of 2015 (IPE, 2016).

The action-research experience was developed based on collective knowledge and decisions, according to the following methods:

1. Mobilization of artisanal fishermen interested in participating in environmental protection actions at Cassurubá RESEX. 
2. Holding gatherings in order to share and level traditional (TPC) and institutional (ICMBio) knowledge, organize groups and monitor teams, select monitoring campaign coordinators, define action strategies, plan the logistics, and to better understand the role to be played by community environmental monitors, management team and partners.

3. Holding gatherings and conversation circles to monitor and evaluate the work carried out during reproduction seasons, as well as to solve conflicts between participants (THIOLLENT, 1986).

Several artisanal fishermen from riverside communities, as well as from Caravelas and Nova Viçosa counties, have shown interest in participating in CEM after the first and successful experience carried out by fishermen in Barra de Caravelas community. This experience was concluded in a public meeting attended by approximately 50 extractivist agents from all three counties (IPE, 2016). This process enabled holding dozens of community meetings and extended CEM's performance to other reproduction seasons of the investigated species. The voluntary adhesion of additional fishermen enabled replicating and improving the current methodology. In addition to the actions and methodological issues associated with CEM, fishermen's involvement process has contributed to the significant expansion of social participation in RESEX management (GALDINO, 2016).

\section{Reflections on environmental protection in Extractive Reserves: common place or management of common goods?}

The involvement of TPCs in the protection of natural resources and the environment within the RESEX's scope requires conceptual dispute and transformative praxis. There are no solutions available for this issue in the institutionalized "common place". Thus, two central problems emerge in the light of theory and empiricism.

The first one lies on favoring the social participation of TPCs in the environmental protection of their traditional territory, without turning it - or even making it look like - a colonizing state-assimilation process, in which appropriation/violence prevails at the expense of regulation/emancipation, which are paradigms based on which Boaventura Sousa Santos (2007) featured the social relations in the Modern Western world.

The second problem lies on overcoming a conservative state culture that understands environmental protection as the exclusive responsibility of State agents, as seen in the lack of legal and infralegal provisions to allow the expressive and unquestionable involvement of TPCs in environmental protection actions (ANDRADE, 2014). Environmental protection in the organizational structure of ICMBio, for example, is based on environmental inspections exclusively performed by public agents (ICMBIO, 2018a). This second problem will be analyzed based on constitutional, international and human rights legal theories and addressed in the next sub-item.

Studies, concepts and methods developed by Elinor Ostrom will be used, in association with theoretical contributions by Antônio Carlos Diegues and David Feeny, in 
order to analyze the first problem.

Ostrom (1990) has established eight principles that can be found in successful cases of self-government of commons in several countries worldwide. Community monitoring stands out among them. This principle received special attention in the document used by the Swedish Royal Academy of Sciences to present the Nobel Prize in Economics awarded to Elinor Ostrom, who was the first woman and heterodox economist to be granted with an award:

Other principles are more surprising. For example, Ostrom proposes that (iv) monitoring and sanctions should be carried out either by users themselves, or by someone held accountable by them. This principle challenges conventional ideas, according to which, these activities should be performed by impartial third parties, but it also raises a series of questions about the reason why individuals are willing to undertake costly monitoring and sanction procedures. (NOBEL, 2009, p. 11).

Antônio Carlos Diegues (2001a) has analyzed the principle of community monitoring proposed by Ostrom, in an article published in Espaços e Recursos Naturais de Uso Comum (Common Use Spaces and Natural Resources) ${ }^{4}$, and also highlighted it as one of the most relevant principles in the case of TPCs at Mamirauá Ecological Station. He described it as follows: "once the most important decisions are made on a consensual basis, monitoring is performed by community members themselves" (DIEGUES, 2001a, p. 118).

Based on survey, analysis, systematization and presentation of hundreds of empirical examples in different regions worldwide, Elinor Ostrom and her research group have shown the likelihood of having a participatory community management accountable for the ordering and sustainable use of natural resources (CHRISTMANN; VIEIRA, 2014). Thus, experiences of this nature are perfectly compatible to the legal and conceptual precepts constituting the RESEX (BRASIL, 2000; CHRISTMANN; VIEIRA, 2014) because collective actions, in these cases, are desirable, viable and effective (FEENY et al., 1990).

\section{TPCs participation in environmental protection and their legality}

TPCs' performance in environmental protection actions implemented in their traditional territory was analyzed through the lens of legal sciences, mainly through the perspective of constitutional, international and human rights laws; the right and duty of these peoples on the subject stood out. Consequently, it was possible perceiving the likelihood of overcoming the current conservatism level prevailing in the guidelines and institutional designs of Brazilian environmental agencies.

However, one should not underestimate the epistemological obstacles caused by the modern - although archaic - positive and conceptual hegemony supported by the public x private law dichotomy (CHRISTMANN; VIEIRA, 2014). Because it is a sci- 
entific simplification with ancient and deep ramifications capable of influencing debates on these environmental issues (HARDIN, 1968), such a dichotomy can impose severe obstacles to the understanding of contemporary legal concepts that hinder their inclusion in one of these two poles.

The International Labor Organization Convention n. 169, also known as ILO 169, has guaranteed - in its article 15 - the right of TPCs to manage and conserve natural resources available in their traditional territory, as follows:

The rights of the peoples concerned to the natural resources available in their land must be especially protected. They include the right of these peoples to participate in the use, management and conservation of the aforementioned resources (emphasis added). (BRASIL, 2004, p.1).

Several principles inscribed in the Brazilian Constitution, which were influenced and corroborated by relevant theoretical analyzes conducted by important constitutionalists, provide a solid basis to guarantee people's participation in national matters. In compliance with ILO 169, the 1988 Federal Constitution, Article 225, could not be more explicit about the role played by communities in environmental protection and preservation when it proposes a system of shared responsibilities (LEITE; AYALA, 2004):

Art. 225. All individuals have the right to an ecologically balanced environment, which is a good of common use to the people and essential to enable good quality of life. Thus, the Public Power and the community have the duty to protect and preserve it for the present and future generations. (BRASIL, 1988, p. 1).

The democratic principle assimilated by the Brazilian legal system and influenced by the legal theory by José Gomes Canotilho (1995) guarantees people's participation in several devices described in the 1988 Federal Constitution (CHRISTMANN; VIEIRA, 2014). The Citizen Constitution has defined environment as a good of common use to the people, as well as imposed the duty to protect and preserve it over the community. The mere association of this constitutional determination with the supraconstitutional provision that guarantees the right of TPCs to manage and conserve the natural resources available in their traditional territory, per se, delegitimizes any institutional misunderstanding that intends to prevent, or even ignore, the direct participation of TPCs in issues associated with the environmental protection of their traditional territory.

\section{Community environmental monitoring (CEM): a case of action-research and management of common goods}

Based on the analysis applied to the CEM case, it was possible perceiving that the aforementioned references - whether conceptual, theoretical, empirical or legal - are remarkably harmonized with the popular participation model developed by artisanal fishermen, management team and partners of Cassurubá RESEX for approximately four years. It was possible noticing important conceptual elements analyzed by Elinor Ostrom, 
Antônio Carlos Diegues and David Feeny.

The analysis applied to the eight principles established by Ostrom (1990), based on the herein investigated successful empirical cases of self-government of common goods, has evidenced the certain incidence of at least six of them in CEM, starting with the ones already mentioned in the current article, namely: "the monitoring performed by communities themselves"; "the definition of clear rules", which is a principle exercised during meetings in order to level and share knowledge; and "appropriate conflict resolution mechanisms" such as gatherings and conversation circles focused on monitoring and evaluating the performance of monitoring campaigns (GALDINO, 2016; MACHADO; VOTTA, 2018; IPE, 2016).

It was also possible observing the incidence of three other principles listed by Ostrom (1990 apud MAHA, 2009, p. 24) in CEM: "sanctions should be moderated in the first violation and get more rigid as violations are repeated". As most community environmental monitors naturally have such an understanding, they have always valued environmental awareness and persuasion, as well as indicated to ICMBio the gradual increase of sanctions applied to other fishermen, whenever necessary; "governance is mostly effective when decision-making processes are democratic, i.e., when most users are allowed to participate in rule-changing processes" (OSTROM, 1990 apud MAHA, 2009, p. 24). This factor is clearly perceived in CEM, to the extent that decisions about the work developed by community monitors were collectively debated and made. Finally, the most important principle for the institutional reflection carried out in the current article states that "the right of users to self-organize is clearly acknowledged by external authorities" (OSTROM, 1990 apud MAHA, 2009, p. 24). This right was acknowledged by the Cassurubá RESEX management team since CEM's origin and conception, despite the lack of any institutional guideline in this respect (GALDINO, 2016; MACHADO; VOTTA, 2018; IPE, 2016).

Since CEM was implemented as a pilot project counting on the participation of 12 Barra de Caravelas community fishermen, during the shrimp reproduction season in the second half of 2015, it has expanded to other 16 reproduction seasons, in addition to those of swamp ghost crab and sea bass ${ }^{5}$. In total, 113 fishermen from the riverside region, from Ponta de Areia district, from Barra de Caravelas village, from Caravelas and Nova Viçosa counties, and from Aparaju district in Alcobaça County ${ }^{6}$ have participated in CEM (ICMBIO, 2018b).

The accounts recorded by the cinematographic documentary entitled Cuidando do Meu Lugar (Taking Care of My Place) translate, in a wise and simple way, the understanding of artisanal fishermen involved in CEM, as shown in the excerpts transcribed below:

5 - CEM's operating periods, until September 2018, comprised: one for shrimps, in 2015; two for shrimps and one for sea bass, in 2016; two for shrimps, one for sea bass and three for swamp ghost crabs, in 2017; and two for shrimps, one for sea bass and three for swamp ghost crabs, in 2018.

6 - Fishermen in Alcobaça County (one of the three counties covered by Cassurubá RESEX area) did not show interest in participating in CEM until September 2018.

7 - Produced by filmmaker and cultural producer Jaco Galdino (2016), this documentary presents CEM based on the accounts of fishermen, environmental analysts and partners. 
People thought [...] "Ah! Because fishermen cannot do that. The police are the ones who must do it, they win, they do it and win [...] "On the contrary. When the police were armed on boats, we were the ones who were afraid. Nowadays, it is different. Nowadays, the heads of household, whose livelihood depends on the water, are the ones helping their colleagues to do the work. (Raildo Pereira, fisherman and member of the Residents' Association of Cassurubá Extractive Reserve - AMAR).

The thing is, if we don't protect it, nobody else will, right? Because, if fishermen, who know the sea the way we know it, cannot protect it, I think that nobody else can. So, it is important because of that. And when we do the monitoring, we prevent the Federal Police and IBAMA itself (currently ICMBio), who used to fine us and approach us in a more aggressive way, from coming [...] Nowadays, it is different; nowadays we approach the fishermen, talk to them, they comply and the problem is solved (Tadeu Augusto, fisherman and AMAR member).

Fishermen feel even more secure, don't they? Because the supervisory bodies [...] They have the technique, but they don't have the practice. We know the tide, the wind and where [...] The place where the product will be, don't we? In this case, the shrimp. So, we act straight on it, but the inspectors do not [...] Inspections sometimes come up empty handed. And we don't. Even some people who committed the crime of trawling there during the reproduction season said that they prefer IBAMA, that they don't want fishermen to do it, right? But we want it [...] The community, we want it, and as an institution, Fishermen's Colony, we want it like that [...] It is a great benefit, isn't it? It is benefiting the whole class. Then, the Colony approved it in minutes. (Antônio Jorge Birindiba, fisherman, president of Colony Z29 and vice president of AMAR).

The Mother Association of Cassurubá Extractive Reserve Residents (AMAR) has started a collective construction movement in the second semester of 2017 in order to take over CEM coordination, since, until then, the RESEX management team accounted for mobilizing, facilitating and reporting the meetings. After few construction months, AMAR, which already had organizational autonomy, has planned, organized and implemented actions focused on protecting shrimp and sea bass reproduction processes in 2018, and it was always supported by ICMBio. In addition, it started developing internal regulation for CEM in August 2018, which described monitors' performance in detail and established new criteria for individuals' participation in it:

The work is split into groups. An output scale is made, with time, date and groups. Each fisherman has a record of occurrence. If they find an occurrence, they try to talk about it and explain the law and, whenever 
necessary, they call ICMBio, although never to play the role of supervisor. The following criteria must be met for individuals to become a CEM monitor: i) participating in meetings held by resex and the mother association, ii) participating in resex activities and meetings, iii) committing to community environmental monitoring actions, and iv) sharing activities and recording occurrences. (MACHADO; VOTTA, 2018, p. 4).

This construction started during another important action focused on CEM developed by AMAR members, also in 2018, namely: Pedagogical Workshops for Community Environmental Monitoring. Such workshops resulted from the III Social and Environmental Management (SEM) Training Cycle (FONTANA et al., 2015) promoted by ICMBio and attended by Alan Machado (fisherman, president of Colony Z25 and AMAR member) and Eduardo Votta (environmental analyst at IBAMA and coordinator of the Environmental Education Center - NEA-BA). These workshops gave fishermen the opportunity to talk to each other and to improve CEM, as well as to establish a new partnership with IBAMA (MACHADO; VOTTA, 2018).

\section{Exchanging common goods' management experiences: CEM and environmental fishery patrol (AHOMAR)}

The exchange between artisanal fishermen from Cassurubá RESEX and Guanabara Bay (Rio de Janeiro) was an extremely important event for both initiatives; and evaluating it helped improving the reflection proposed in the current article. Cassurubá RESEX management team started mapping institutions and social movements willing to support community strengthening actions focused on extractivism, back in 2015 (ICMBIO, 2015). The Association of Sea Men and Women of Guanabara Bay (AHOMAR), which came to the attention of the management team through the cinematographic documentary entitled Vento Forte ${ }^{8}$ (Strong Wind), was one of the contacted entities.

Artisanal fishermen linked to AHOMAR, in opposition to the serious environmental degradation caused by the oil industry in Guanabara Bay and dissatisfied with the performance of the accountable public bodies, have started an intense and organized popular resistance movement (COELHO, 2017). Among the several resistance strategies adopted to survive this socio-environmental conflict, AHOMAR has developed the Environmental Fishery Patrol, according to which:

[...] fishermen take turns in the environmental monitoring of Guanabara Bay by using their own boats, equipped with cell phones used to record or photograph illicit activities and damage to the ecosystem in order to formalize complaints to be reported to control bodies (COELHO, 2017, p. 137-138).

8 - The documentary entitled Vento Forte, produced by the Fishermen's Pastoral Council (CPP - Conselho Pastoral dos Pescadores) in 2015, presents several cases of socio-environmental conflicts between artisanal fishermen and large polluting enterprises along the Brazilian coast. 
Upon accepting the invitation from Cassurubá RESEX management team to participate in the meeting held by the Thematic Dredging Chamber, linked to the RESEX Deliberative Council - which aim at presenting the documentary Vento Forte -, the AHOMAR board has started a long-term and promising exchange with artisanal fishermen from Cassurubá. Among several shared experiences, it is possible highlighting the exchange between the Environmental Fishery Patrol and CEM, which resulted in a fruitful knowledge exchange, as described by Breno Herrera da Silva Coelho (2017, p. 138):

The success of the initiative has already led AHOMAR fishermen to be invited by the fishermen's association of Cassurubá Marine Extractive Reserve, Southern Bahia, to visit the area and exchange information about this community patrolling type, and it started a promising exchange between traditional extractivist populations from the Brazilian coast in practical socio-biodiversity conservation actions, with popular protagonism.

One of the practical results of this exchange lies on assimilating the suggestion made by Alexandre Anderson (artisanal fisherman and president of AHOMAR) to extend CEM's actions to the monitoring of dredging activities carried out by Fibria Celulose SA in the traditional territory of Cassurubá RESEX fishermen. This suggestion was accepted and incorporated by CEM in the 2018 planning (MACHADO; VOTTA, 2018).

\section{CEM and the governance of oceans}

The global agenda for the protection of oceans has been strengthened in recent decades and many actions taken to protect this environment are still considered innovative. Thus, Brazil needs to advance in the elaboration of public policies, environmental control and protection strategies, territorial ordering and governance of marine resources (BARROS-PLATIAU et al., 2015).

Cassurubá RESEX is located in Banco dos Abrolhos, which is the region concentrating the largest coastal and marine biodiversity in the entire South Atlantic Ocean (LEÃO, 1999). It also protects approximately 11,000 hectares of mangroves, as well as endemic and endangered species (REPINALDO, 2016). These features and attributes are essential to enable the connectivity between the coastal and marine environment of Abrolhos National Marine Park (MMA, 2007), which is protected since the 1980 s, due to its unparalleled biological relevance. The interdependence of environments protected by Cassurubá RESEX and the Abrolhos National Marine Park - from marine dynamics to the reproductive cycle of species - makes the role played by community environmental monitors even more important for the entire Banco dos Abrolhos region, since it results in environmental benefits that go beyond their traditional fishing territories.

Artisanal fishermen have unique knowledge about the sciences of the sea, their knowledge has traditionally been passed on from generation to generation, which allows these social actors to have an intimate relationship with this environment (TROUILLET et al., 2019). Such idiosyncrasy turns these individuals into fundamental elements 
in maritime spatial planning processes. Thus, CEM enables using traditional knowledge about tides, lunar phases, wind dynamics, sea currents and spatial location of species to help conserving fishing resources and, consequently, the oceans. In addition, CEM contributes to humanize and broaden the understanding of state inspection agents, since it, consequently, leads to greater efficiency in protection actions.

Another relevant aspect lies on the fact that educational actions proposed by CEM monitors allowed greater acceptance about the importance of prohibiting speciescapturing during their reproduction season. Based on the perception of interviewed fishermen, language, approach method and educational character transmitted by monitors to their fishing colleagues enable reducing the number of environmental infractions and substantially improving the protection of the reproduction seasons of target species (GALDINO, 2016).

Another important result lies on the fact that the artisanal fishermen involved in CEM have significantly increased the feeling of belonging to their traditional territory. In other words, these social actors - who constantly live at sea - get involved in educational actions and develop a strong feeling of belonging to the territory, because they realize that they can actively help taking care of the place they live in. This relationship is of paramount importance to maintain the way of life of these traditional communities and, consequently, to enable local biodiversity conservation.

\section{Final considerations}

By observing CEM history and features through the conceptual and theoretical lenses adopted by Ostrom, Diegues and Feeny on the management of common goods, it was possible seeing a legitimate example of the good practices of local solutions. Besides challenging the hegemonic model limited by the public x private law dichotomy, this example offers efficient, genuinely participatory and very respectful solutions to the rights of TPCs over their traditional territories.

As for the legal aspects of this bold social participation proposal, its legality is evidenced when it is exposed to scrutiny by the legal sciences, mainly by constitutional, international and human rights law. In order to do so, one must pay attention to the notes about the Brazilian legal system presented in this article through precise and expressive statements inserted in constitutional and supraconstitutional provisions.

The aims of the current action-research were to analyze and present a practical and successful experience in the management of commons, as well as to carry out a critical, social and institutional analysis of the conventional environmental protection model adopted by the State. It was done to avoid promoting sterile theoretical daydreams or even boring rhetorical speeches. In fair opposition to this type of intellectual dishonesty, the present article has the firm and lucid intent to be an element of transformation in the relationships between the Brazilian State (environmental bodies, mainly, ICMBio) and Traditional Peoples and Communities, mainly the one inserted in the context of Extractive Reserves. Thus, the current study is expected to promote conceptual, normative and 
institutional advancements capable of enabling an effective social participation and shared management culture, as well as of strengthening the institutional respect for the existence and protagonism of Traditional Peoples and Communities in their traditional territories.

\section{Acknowledgment}

The most sincere feeling of gratitude to our fishing sisters and our fishing brothers from the Extractive Reserve of Cassurubá for their friendship, learning and solidarity. Gratitude is a memory that is kept alive.

\section{Note}

This article is the result of a thesis, supervised by Dr. Ísis Aparecida Conceição, from the Specialization in State and Rights of Traditional Peoples and Communities at the Faculty of Law of the Federal University of Bahia.

\section{References}

AMÂNCIO, A. B. Gestão participativa dos recursos naturais e desenvolvimento de comunidades sustentáveis na Amazônia brasileira: estudo de caso dos agentes ambientais voluntários na reserva de desenvolvimento sustentável Mamirauá. Manaus: UFAM, 2006.

ANDRADE, Y. O. O poder de polícia ambiental exercido pelo particular e a (i)legalidade no direito brasileiro. Belo Horizonte: ESDHC, 2014.

BARROS-PLATIAU, A. F.; BARROS, J. G. C.; MAZZEGA, P.; OLIVEIRA, L. P. S. Race to the sea in the anthropocene: the complexity of oceans governance and the brazilian strategy for the marine resources management. Brazilian Journal of International Law, v. 12, n. 1, p. 150-168, 2015.

BOURDIEU, P. Sobre o Estado: cursos no Collège de France (1989-1992). São Paulo: Companhia das Letras, 2014.

BRASIL. Constituição (1988). Constituição da República Federativa do Brasil de 1988. Disponível em: http://www.planalto.gov.br/ccivil_03/constituicao/constituicaocompilado.htm. Acesso em: 20 set. 2018.

BRASIL. Decreto de 5 de junho de 2009. Dispõe sobre a criação da Reserva Extrativista de Cassurubá, nos Municípios de Caravelas, Alcobaça e Nova Viçosa, no Estado da Bahia, e dá outras providências. Disponível em: http://www.planalto.gov.br/ccivil_03/_Ato2007-2010/2009/ Dnn/Dnn12058.htm. Acesso em: 20 set. 2018.

BRASIL. Decreto n. ${ }^{\circ}$ 5.051, de 19 de abril de 2004. Promulga a Convenção no 169 da Organização Internacional do Trabalho - OIT sobre Povos Indígenas e Tribais.- Disponível em: http://www.planalto.gov.br/ccivil_03/_ato2004-2006/2004/decreto/d5051.htm. Acesso em: 20 set. 2018. 
BRASIL. Lei n.o 11.516 , de 28 de agosto de 2007. Dispõe sobre a criação do Instituto Chico Mendes de Conservação da Biodiversidade - Instituto Chico Mendes; altera as Leis nos 7.735, de 22 de fevereiro de 1989, 11.284, de 2 de março de 2006, 9.985, de 18 de julho de 2000, 10.410, de 11 de janeiro de 2002, 11.156, de 29 de julho de 2005, 11.357, de 19 de outubro de 2006, e 7.957, de 20 de dezembro de 1989; revoga dispositivos da Lei no 8.028, de 12 de abril de 1990, e da Medida Provisória no 2.216-37, de 31 de agosto de 2001; e dá outras providências. Disponível em: http://www.planalto.gov.br/ccivil_03/_Ato2007-2010/2007/Lei/L11516.htm. Acesso em: 20 set. 2018.

BRASIL. Lei n. 9 9.985, de 18 de julho de 2000. Regulamenta o art. 225, § 1o, incisos I, II, III e VII da Constituição Federal, institui o Sistema Nacional de Unidades de Conservação da Natureza e dá outras providências. Disponível em: http://www.planalto.gov.br/ccivil_03/LEIS/L9985. htm. Acesso em: 20 set. 2018.

BRASIL. Ministério do Meio Ambiente. Portaria n. 349, de 2014. Disponível em: http://www. mma.gov.br/images/arquivos/areas_protegidas/gef-mar/Portaria-349-26set14-Dou29set14.pdf. Acesso em: 20 set. 2018.

CANOTILHO, J. J. G. Direito constitucional. Coimbra: Almedina, 1995.

CHRISTMANN, L. L.; VIEIRA, R. S. Gestão de bens comuns: Tragédia dos comuns ou tragédia dos comunitários? Reflexões em torno da gestão de unidades de conservação de uso sustentável. In: CAMPELLO, Livia Gaigher Bosio; PADILHA, Norma Sueli; ANTUNES, Paulo de Bessa. (orgs.). Direito ambiental I. Florianópolis: CONPEDI, 2014. p. 361-389.

COELHO, B. H. S. Potencialidades e limites de conselhos de unidades de conservação: considerações sobre a implantação do Comperj na região do Mosaico Central Fluminense. Rio de Janeiro: UFRJ, 2017.

DI PIETRO, M. S. Z. Discricionariedade administrativa na Constituição de 1988. 3. ed. São Paulo: Atlas, 2012.

DIAS NETO, J. Análise do seguro-desemprego do pescador artesanal e de possíveis benefícios para a gestão pesqueira. Brasília: IBAMA, 2017.

DIEGUES, A. C. Espaços e recursos naturais de uso comum. São Paulo: NUPAUB, 2001a.

DIEGUES, A. C. O mito moderno da natureza intocada. São Paulo: HUCITEC, 2001 b.

FEENY, D. H.; BERKES, F.; MCCAY, B. J.; ACHESON, J. M. The Tragedy of the Commons: twenty-two years later. Human Ecology, v. 18, p. 1-19, mar. 1990.

FLORIANI, D. Conhecimento científico: racionalidade instrumental e cultura. Rio de Janeiro: Jornal da Ciência: SBPC, 2001.

FONTANA, A.; CARVALHO MARTINS, J.; CUNHA, C. C.; SANTIN, L.; FABIANO, F; DINO, K. Promoção da participação social na gestão ambiental pública: a formação de gestores ambientais no ICMBio. In: Seminário Brasileiro sobre Áreas Protegidas e Inclusão Social - SA- 
PIS, 7. Encontro Latino Americano sobre Áreas Protegidas e Inclusão Social - ELAPIS, 2. 2015. Anais... Santa Catarina, 2015. p. 879-886.

GALDINO, J. S. Cuidando do meu lugar. 2016. Disponível em: https://www.youtube.com/wat $\mathrm{ch} ? \mathrm{v}=$ useyifCdAsg\&list $=$ PLwIoEO_omXz1LosaETWIZM8eskhBquOy-\&index $=1$. Acesso em: 20 set. 2018.

HARDIN, G. The tragedy of the commons. Science, New Series, Washington, v. 162, n. 3859, p. 1243-1248, dec. 1968.

IBAMA - Instituto Brasileiro do Meio Ambiente e dos Recursos Naturais Renováveis. Instrução Normativa Ibama n. ${ }^{\circ}$ 66, de 12 de maio de 2005. Disponível em: http://www.icmbio.gov.br/ cepsul/images/stories/legislacao/Instrucao_normativa/2005/in_ibama_66_2005_programasagentesambientaisvoluntarios.pdf. Acesso em: 20 set. 2018.

ICMBIO - Instituto Chico Mendes de Conservação da Biodiversidade. Organograma. Decreto 8.974 de 24 de janeiro de 2017. 2018a. Disponível em: http://www.icmbio.gov.br/portal/images/ stories/voluntariado/2018Organograma.pdf. Acesso em: 20 set. 2018a.

ICMBIO - Instituto Chico Mendes de Conservação da Biodiversidade. Plano de ação do conselho deliberativo. Caravelas: RESEX Cassurubá, 2015.

ICMBIO - Instituto Chico Mendes de Conservação da Biodiversidade. Lista dos Monitores Ambientais Comunitários. Caravelas: RESEX Cassurubá, 2018b.

ICMBIO - Instituto Chico Mendes de Conservação da Biodiversidade. Plano de manejo. Caravelas: RESEX Cassurubá, 2019.

IPE - Instituto de Pesquisas Ecológicas. Boas práticas na gestão de unidades de conservação. 2016. p. 126-128. Disponível em: http://www.ipe.org.br/ultimas-noticias/805-revista-boas-praticas-na-gestao-de-unidades-de-conservacao-leia-aqui-2. Acesso em: 15 set. 2018.

LEÃO, A. R. Do projeto a um plano nacional de conservação e uso sustentável dos manguezais do Brasil em unidades de conservação. Rio de Janeiro: Instituto de Pesquisas Jardim Botânico do Rio de Janeiro, Escola Nacional de Botânica Tropical, 2017.

LEÃO, Z. M. A. N. Abrolhos - O complexo recifal mais extenso do Oceano Atlântico Sul. In: SCHOBBENHAUS, C.; CAMPOS, D. A.; QUEIROZ, E. T.; WINGE, M.; BERBERT-BORN, M. (edits.) Sítios geológicos e paleontológicos do Brasil. 1999. Disponível em: http://sigep. cprm.gov.br/sitio090/sitio090.htm. Acesso em: 23 jun. 2019.

LEITE, J. R. M.; AYALA, P. A. Direito ambiental na sociedade de risco. Rio de Janeiro: Forense Universitária, 2004.

LITTLE, P. Territórios sociais e povos tradicionais no Brasil. Por uma antropologia da territorialidade. Série Antropologia, n. 322. Brasília: Departamento de Antropologia, 2002.

MACHADO, A. S.; VOTTA, E. F. Oficinas pedagógicas do monitoramento ambiental comu- 
nitário. Caravelas: ICMBio-RESEX Cassurubá, 2018.

MAHA, G. Governança econômica. Boletim da Sociedade de Economia Ecológica, n. 21, p. 21-24, maio/jun./jul./ago. 2009.

MELLO, C. C. A. Do meio do medo nasce a coragem: o encontro entre pescadores e marisqueiras de Caravelas (BA) e do Ceará e os múltiplos sentidos da política. Revista Brasileira de Estudos Urbanos e Regionais, Recife, v. 17, n. 3, p. 134-149, set./dez. 2015.

MMA - Ministério do Meio Ambiente. Ficha das áreas prioritárias para a conservação, uso sustentável e repartição dos benefícios da biodiversidade brasileira. 2007. Disponível em: http://www.mma.gov.br/estruturas/sbf_chm_rbbio/_arquivos/marinho_fichas_das_areas_prioritarias.pdf. Acesso em: 23 jun. 2019.

MÓNICO, L. S.; ALFERES, V. R.; CASTRO, P. A.; PEREIRA, P. M. A observação participante enquanto metodologia de investigação qualitativa. Revista de Investigação Qualitativa em Ciências Sociais, volume 3, 2017.

MOURA, G. G. M. Guerras nos mares do sul: a produção de uma monocultura marítima e os processos de resistência. São Paulo: USP, 2014.

MOURA, R.L.; FRANCINI-FILHO, R.B. Reef and shore fishes of the Abrolhos Region, Brazil. Washington, DC: RAP Bulletin of Biological Assessment, 38: 40-55., 2005.

NOBEL. Economic Governance. Scientific Background on the Sveriges Riksbank Prize in Economic Sciences in Memory of Alfred Nobel 2009. Stockholm: The Royal Swedish Academy of Sciences, 2009.

OLSON, M. A lógica da ação coletiva: os benefícios públicos e uma teoria dos grupos sociais São Paulo: Edusp, 2015.

OSTROM, E. Governing the commons: the evolution of institutions for collective action. New York: Cambridge University Press, 1990.

ORLANDI, E. Análise de Discurso: princípios e procedimentos. Campinas: Pontes, 1999.

PAWLOSKI, C. S.; ANDERSEN, H.B.; TROELSEN, J.; SCHIOOERIJN, J. Children's physical activity behavior during school recess: A pilot study using GPS, accelerometer, participant observation, and go-along interview. Plos One, 11 (2), 2016.

REPINALDO, M. G. M. Mapeamento dos ambientes de manguezal do sistema estuarino Caravelas-Nova Viçosa - BA (RESEX de Cassurubá) através de classificação orientada a objetos geográficos: subsídio para proteção e manejo. 2016. Dissertação (Mestrado em Biologia Ambiental) - Programa de Pós-Graduação, Universidade Federal do Pará, Bragança, Pará, 2016.

SANTOS, B. S. Para além do pensamento abissal: Das linhas globais a uma ecologia de saberes. São Paulo: Novos Estudos CEBRAP, 2007. 
SPRADLEY, J. P. Participant observation. Orlando: Harcourt Brace Jovanovich College Publishers, 1980.

THIOLLENT, M. Metodologia da pesquisa-ação. 2a Ed. São Paulo: Cortez,1986.

TROUILLET, B.; BELLANGER-HUSI, L.; EL GHAZIRI, A.; LAMBERTS, C.; PLISSONNEAU, E.; ROLLO, N. More than maps: Providing an alternative for fisheries and fishers in marine spatial planning. 2019. Disponível em: https://doi.org/10.1016/j.ocecoaman.2019.02.016. Acesso em: 23 jun. 2019. 
Marcelo Lopes

$\square$ marcelo.lopes@icmbio.gov.br

ORCiD: https://orcid.org/0000-0001-6089-8412

\section{Pedro Henrique Dias Marques}

$\square$ pedro.ufmg.dias@gmail.com

ORCiD: https://orcid.org/0000-0003-0211-4610

\section{Priscilla Correa de Moura Estevão}

$\square$ priscilla.estevao@icmbio.gov.br

ORCiD: https://orcid.org/0000-0002-2943-035x
Submitted on: $16 / 08 / 2019$

Accepted on: 10/09/2020

2021;24e:01532

How to cite: LOPES1, M.; MARQUES2, P. H. D.; ESTEVÃO3, P. C. M. Community Environmental Monitoring: the management of Commons in Cassurubá Extractive Reserve. Ambiente \& Sociedade. São Paulo, v. 24, p. 1-20, 2021. 


\title{
Monitoramento Ambiental Comunitário: a gestão dos bens comuns na Reserva Extrativista de Cassurubá
}

\author{
Marcelo Lopes \\ Pedro Henrique Dias Marques \\ Priscilla Correa de Moura Estevão
}

São Paulo. Vol. 24, 2021

Artigo Original
Resumo: Este artigo objetiva refletir sobre o direito de participação dos Povos e Comunidades Tradicionais (PCT) na proteção ambiental dos seus territórios tradicionais em Reservas Extrativistas (RESEX), analisando-se o caso concreto do Monitoramento Ambiental Comunitário (MAC) que ocorre na RESEX Cassurubá. Busca-se uma estruturação conceitual sobre o tema; para tal, são utilizados alguns estudos e teorias dedicados à gestão dos bens comuns. Após, são analisados os aspectos legais, positivos e conceituais presentes no ordenamento jurídico nacional e internacional que delineiam o alcance da participação social em assuntos relacionados ao meio ambiente. Analisam-se também o histórico, as principais características e o contexto institucional no qual o MAC está inserido. Como instrumentos metodológicos participativos, foram utilizadas a pesquisa-ação, observação participante e rodas de conversa. Com efeito, o MAC apresenta-se como um bom exemplo na gestão dos bens comuns, principalmente por garantir os direitos dos PCT.

Palavras-chave: Bens Comuns; Reserva Extrativista; Monitoramento Ambiental Comunitário; Gestão Participativa; Unidade de Conservação.

Como citar: LOPES, M.; MARQUES2, P. H. D.; ESTEVÃO3, P. C. M. Monitoramento Ambiental Comunitário: a gestão dos bens comuns na Reserva Extrativista de Cassarubá. Ambiente \& Sociedade. São Paulo, v. 24, p. 1-20, 2021. 


\title{
Monitoreo Ambiental Comunitario: la gestión de los bienes comunes en la Reserva Extractiva de Cassurubá
}

\author{
Marcelo Lopes \\ Pedro Henrique Dias Marques \\ Priscilla Correa de Moura Estevão
}

São Paulo. Vol. 24, 2021

Artículo original
Resumen: Este articulo tiene como objetivo reflexionar sobre el derecho de participación de los Pueblos y Comunidades Tradicionales en la protección ambiental de sus territorios tradicionales en Reservas Extractivas (RESEX), analizándose el caso concreto del Monitoreo Ambiental Comunitario (MAC) que ocurre en RESEX Cassurubá. Se busca una estructuración conceptual sobre el tema; para esto, son utilizados algunos estudios y teorías dedicadas a la gestión de los bienes comunes. Luego, son analizados los aspectos legales, positivos y conceptuales presentes en el orden jurídico nacional e internacional que delinean el alcance de la participación social en asuntos relacionados al medio ambiente. Finalmente, se analiza el histórico, las principales características y el contexto institucional en el cual el MAC está inserto. Como instrumento metodológico, fueron utilizados: la investigación-acción, la observación participante y las ruedas de conversación. De hecho, el MAC es un buen ejemplo en la gestión de los bienes comunes, principalmente porque garantiza los derechos del PCT.

Palabras-clave: Bienes Comunes; Reserva Extractive; Monitoreo Ambiental Comunitario; Gestión Participative; Área Protegida.

Como citar: LOPES, M.; MARQUES2, P. H. D.; ESTEVÃO3, P. C. M. Monitoreo Ambiental Comunitário: la gestión de los bienes comunes em la Reserva Extractiva de Cassurubá. Ambiente $\mathbb{\&}$ Sociedade. São Paulo, v. 24, p. 1-20, 2021. 